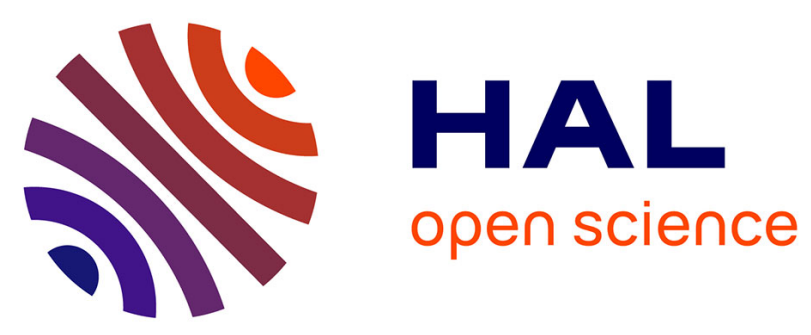

\title{
Proteins for the future: A soft matter approach to link basic knowledge and innovative applications
}

\author{
Adeline Boire, Antoine Bouchoux, Said Bouhallab, Anne Laure Chapeau, \\ Thomas Croguennec, Vincenza Ferraro, Valérie Lechevalier-Datin, Paul \\ Menut, Stephane Pezennec, Denis Renard, et al.
}

\section{To cite this version:}

Adeline Boire, Antoine Bouchoux, Said Bouhallab, Anne Laure Chapeau, Thomas Croguennec, et al.. Proteins for the future: A soft matter approach to link basic knowledge and innovative applications. Innovative Food Science \& Emerging Technologies / Innovative Food Science and Emerging Technologies , 2018, 46, pp.18-28. 10.1016/j.ifset.2017.06.012 . hal-01608238

\section{HAL Id: hal-01608238 \\ https://hal.science/hal-01608238}

Submitted on 26 May 2020

HAL is a multi-disciplinary open access archive for the deposit and dissemination of scientific research documents, whether they are published or not. The documents may come from teaching and research institutions in France or abroad, or from public or private research centers.
L'archive ouverte pluridisciplinaire HAL, est destinée au dépôt et à la diffusion de documents scientifiques de niveau recherche, publiés ou non, émanant des établissements d'enseignement et de recherche français ou étrangers, des laboratoires publics ou privés. 


\section{Accepted Manuscript}

Proteins for the future: A soft matter approach to link basic knowledge and innovative applications

Adeline Boire, Antoine Bouchoux, Saïd Bouhallab, Anne-Laure Chapeau, Thomas Croguennec, Vincenza Ferraro, Valérie Lechevalier, Paul Menut, Stéphane Pézennec, Denis Renard, Véronique Santé-Lhoutellier, Karima Laleg, Valérie Micard,

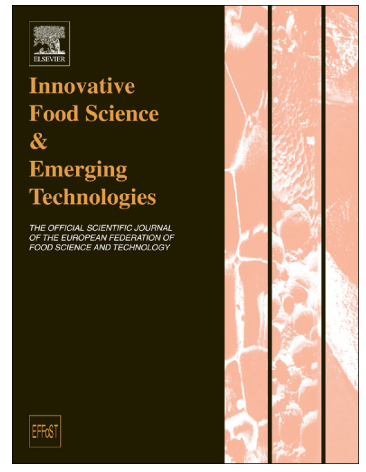
Alain Riaublanc, Marc Anton

PII: S1466-8564(17)30240-0

DOI: doi: $10.1016 /$ j.ifset.2017.06.012

Reference: INNFOO 1780

To appear in: Innovative Food Science and Emerging Technologies

Received date: 24 February 2017

Revised date: 19 May 2017

Accepted date: 24 June 2017

Please cite this article as: Adeline Boire, Antoine Bouchoux, Saïd Bouhallab, AnneLaure Chapeau, Thomas Croguennec, Vincenza Ferraro, Valérie Lechevalier, Paul Menut, Stéphane Pézennec, Denis Renard, Véronique Santé-Lhoutellier, Karima Laleg, Valérie Micard, Alain Riaublanc, Marc Anton, Proteins for the future: A soft matter approach to link basic knowledge and innovative applications, Innovative Food Science and Emerging Technologies (2017), doi: 10.1016/j.ifset.2017.06.012

This is a PDF file of an unedited manuscript that has been accepted for publication. As a service to our customers we are providing this early version of the manuscript. The manuscript will undergo copyediting, typesetting, and review of the resulting proof before it is published in its final form. Please note that during the production process errors may be discovered which could affect the content, and all legal disclaimers that apply to the journal pertain. 


\section{Proteins for the future: a soft matter}

\section{approach to link basic knowledge and}

\section{innovative applications}

Adeline Boire ${ }^{1}$, Antoine Bouchoux ${ }^{2}$, Saïd Bouhallab ${ }^{3}$, Anne-Laure Chapeau ${ }^{3}$, Thomas Croguennec ${ }^{3}$, Vincenza Ferraro ${ }^{4}$, Valérie Lechevalier ${ }^{3}$, Paul Menut ${ }^{5,6}$, Stéphane Pézennec ${ }^{3}$, Denis Renard ${ }^{1}$, Véronique Santé-Lhoutellier ${ }^{4}$, Karima Laleg ${ }^{6}$, Valérie Micard ${ }^{6}$, Alain Riaublanc ${ }^{1}$, Marc Anton ${ }^{1}$

${ }^{1}$ UR1268 BIA, Biopolymères Interactions Assemblages, INRA, F-44300 Nantes, France

${ }^{2}$ LISBP, UMR 5504/792 INRA, CNRS, INSA, F-31077 Toulouse, France

${ }^{3}$ UMR1253, STLO, INRA, Agrocampus Ouest, F-35042 Rennes, France

${ }^{4}$ INRA, UR370 Qualité des Produits Animaux, F-63122 Saint Genès-Champanelle, France

${ }^{5}$ UMR Ingénierie Procédés Aliments, AgroParisTech, INRA, Université Paris-Saclay, F-91300 Massy,

France

${ }^{6}$ UMR 1208 IATE, INRA, Montpellier SupAgro, Université de Montpellier, CIRAD, F-34060 Montpellier, France 


\section{Introduction}

In a context of global demographic and food transitions, a shift from the use of animal to alternative (out of which plant) proteins is expected in a near future. This increasing alternative protein content in human diet will bring positive effects on both climate and public health. But before these important changes on dietary practices, a significant research investment is necessary to lay the foundation of these future foods. At the same time and with this objective of sustainability, numerous wastes of animal processing have to be valorized for new non-food applications and this challenge also requires basic scientific knowledge. In this goal, teams of Science for Food and Bioproduct's INRA Division develop for a long time innovative research on food proteins and their interactions in view to imagine these new architectures and/or applications.

From proteins to complex architectures found either in natural (milk, meat, eggs, seeds, ...) or in processed (emulsions, foams, gels, ...) foods, one of the most important scientific challenge is to link the protein molecular structure, self-assemblies mechanisms, supramolecular architectures and their resulting properties. The challenge is to understand the properties of these natural and processed architectures at macroscopic scale, in relation with the organization of the basic components and their interactions at a mesoscopic scale. This involves multiscale approaches requiring methodological and theoretical developments. Furthermore in these disordered materials, energy scale of particle interactions is of the order of thermal energy and such weak interactions allow these colloidal self-assemblies to adopt different phase behavior at thermodynamic equilibrium that can change over time. These systems are thus likely to reorganize strongly under minor environment variations (temperature, pressure, concentration, mechanical stress, ...).

Consequently, this review aims to provide a state of the strengths of the Science for Food and Bioproduct's INRA Division, on the construction of protein architectures with a multidisciplinary research at the interface between physics and biology. In this chapter we will present three main questions that have been explored taking into account different sources of proteins well studied 
from the different teams of CEPIA division: (1) how proteins assemble at air-water and oil-water interfaces ; (2) how protein interactions in single-component solutions drive the properties of protein dispersions at high concentrations ; (3) how starting from more complex mixture can induce specific phase transition also called "heteroprotein complex coacervations". The last part (4) will be focused on two examples of innovative applications dealing with this knowledge.

\section{Part 1. Food protein structures at interfaces}

Interfaces are present in many foodstuffs such as foams (air-liquid interfaces), emulsions (liquidliquid interfaces) and foamed emulsions (air-liquid-liquid interfaces). In food area emulsions and foam-based products formation and stabilization strongly depend on the behavior of proteins at the interfaces. From their amphiphilic nature proteins in solution adsorb spontaneously at hydrophobic interfaces as they are able to change their conformation, which modifies their surface properties (Lechevalier, V., Croguennec, T., Pezennec, S., Guérin-Dubiard, C., Pasco, M. \& Nau, F., 2003). In the confined space near the interface, these modifications favor the formation of many interactions of weak energy (hydrophobic interactions, hydrogen bonds, Van der Waals interactions), and thus the creation, in the interface plane, of a network through intermolecular interactions (Desfougères, Y., Lechevalier, V., Pezennec, S., Artzner, F. \& Nau, F., 2008). Adsorbed proteins can therefore, in favorable conditions, constitute at the interface a continuous film with viscoelastic properties (Pezennec, S., Gauthier, F., Alonso, C., Graner, F., Croguennec, T., Brulé, G. \& Renault, A., 2000). These mechanical properties contribute to the stabilization of the interface created in multiphasic systems such as foams or emulsions.

Protein structure determines their interfacial behavior and thus their foaming properties: ovalbumin, lysozyme and ovotransferrin, for example, show very different foaming properties (Lechevalier, V., Croguennec, T., Pezennec, S., Guérin-Dubiard, C., Pasco, M. \& Nau, F., 2003). This results from 
different interfacial adsorption kinetics and protein organization into the film (Le Floch-Fouéré, C., Pezennec, S., Lechevalier, V., Beaufils, S., Desbat, B., Pézolet, M. \& Renault, A., 2009). Even when considering one single protein, CEPIA's researchers have shown that very slight conformational changes due to thermo-mechanical treatments (Desfougères, Y., Jardin, J., Lechevalier, V., Pezennec, S. \& Nau, F., 2011; Desfougères, Y., Saint-Jalmes, A., Salonen, A., Vié, V., Beaufils, S., Pezennec, S., Desbat, B., Lechevalier, V. \& Nau, F., 2011; Renault, A., Pezennec, S., Gauthier, F., Vié, V. \& Desbat, B., 2002) or physicochemical modifications (Le Floch-Fouéré, C., Pezennec, S., Pasco, M., Paboeuf, G., Renault, A. \& Beaufils, S., 2015; Le Floch-Fouéré, C., Pezennec, S., Pézolet, M., Rioux-Dubé, J.-F., Renault, A. \& Beaufils, S., 2011) strongly influence interfacial protein behavior. These protein conformational changes increase their capacity to self-assemble at the interface resulting in thicker and heterogeneous interfacial layers, and also increasing foam stability (Fig. 1) (Desfougères, Y., Lechevalier, V., Pezennec, S., Artzner, F. \& Nau, F., 2008). 


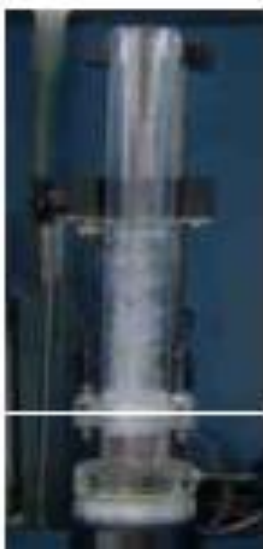

Native

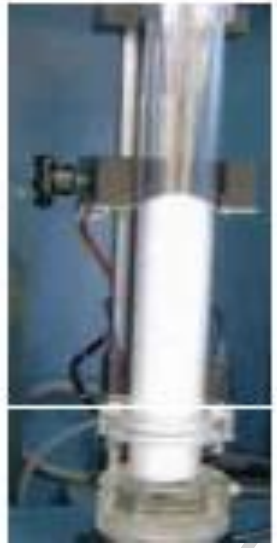

Dry heated

Fig. 1.

Foam of native and dry heated lysozyme $30 \mathrm{~min}$ after the end of bubbling (Desfougères, Y., Lechevalier, V., Pezennec, S., Artzner, F. \& Nau, F., 2008)

\section{Fig. 2.}

Simplified diagram of the interfacial film organization according to the order of protein injection (Le Floch-Fouéré, C., Beaufils, S., Lechevalier, V., Nau, F., Pézolet, M., Renault, A. \& Pezennec, S., 2010)

lysozyme $\bigcirc$ ovalbumin

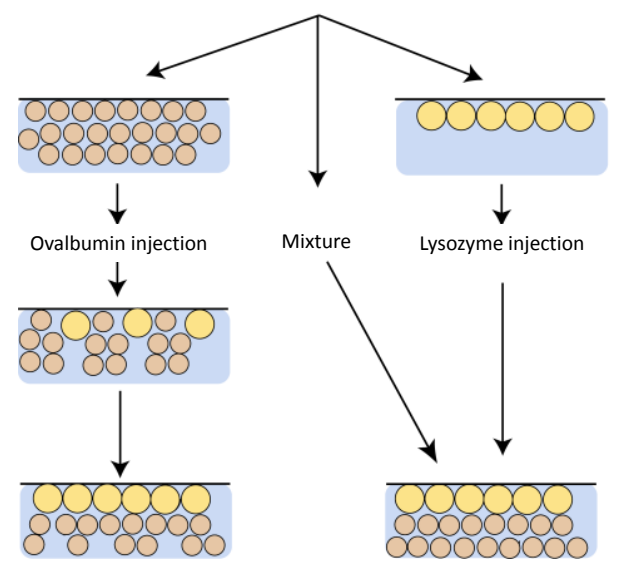


Besides in systems where several proteins with different properties (size, hydrophobicity, charge, conformation flexibility, ...) coexist, the interactions between proteins enhance interfacial behavior that cannot be considered as the sum of the single behaviors. Le Floch-Fouéré et al. (Le Floch-Fouéré, C., Beaufils, S., Lechevalier, V., Nau, F., Pézolet, M., Renault, A. \& Pezennec, S., 2010; Le Floch-Fouéré, C., Pezennec, S., Lechevalier, V., Beaufils, S., Desbat, B., Pézolet, M. \& Renault, A., 2009) using an original approach of sequential adsorption between ovalbumin and lysozyme, thus highlighted a specific and stratified organization of the two proteins inside the interfacial film (Fig. 2). These results incited researchers to understand protein-protein interactions in condensed systems, which will be detailed in the part 2 of this chapter, since protein crowding close to the interface could generate intermolecular interactions of prominent importance in the understanding of interfacial properties. Work is in progress to relate these interfacial and foaming properties to bulk behaviors the issue over time being to control technological parameters to improve interfacial properties in relation to foaming properties.

Another type of egg protein: phosvitin, is used to stabilize food emulsions. Phosvitin is a $35 \mathrm{kDa}$ phosphoglycoprotein with an important negative net charge of about -179 and able to anchor at airwater interfaces in spite of its numerous negative charges (Belhomme, C., David-Briand, E., GuérinDubiard, C., Vié, V. \& Anton, M., 2008; Belhomme, C., David-Briand, E., Ropers, M.-H., GuérinDubiard, C. \& Anton, M., 2007). Two regimes were suggested: in diluted regime, phosvitin molecules could adsorb by their two hydrophobic extremities exhibiting loops in the aqueous phase (hair model), whereas in concentrated regime (high interfacial concentration) it would be adsorbed at the interface by only one extremity (brush model). This model can explain the high flocculation extent observed for yolk at pH7 certainly through hydrophobic interactions.

Furthermore, this team demonstrated that an in situ aggregation (by adding calcium) induced a densification of the interfacial film through lateral interactions and an organization in multilayers, improving stability of emulsions in particular against coalescence. The use of such aggregates in 
acidic emulsions ( $\mathrm{pH} 4$ and $0.75 \mathrm{M} \mathrm{NaCl}$ ) brings remarkable firmness due to a cumulative effect of the frictional forces between the interfacial films and the network built in the aqueous phase by the presence of aggregates. This clearly indicates that we must take into account the impact of connections at the interface, but also in the aqueous phase.

The INRA division, Science for Food and Bioproducts, teams then improved the understanding of the role of protein assemblies at air-water or oil-water interface and their impact on foam or emulsion stability (Audebrand, M., Ropers, M. H. \& Riaublanc, A., 2013; Mahmoudi, N., Axelos, M. A. V. \& Riaublanc, A., 2011; Mahmoudi, N., Gaillard, C., Boue, F., Axelos, M. A. V. \& Riaublanc, A., 2010; Mahmoudi, N., Gaillard, C., Riaublanc, A., Boue, F. \& Axelos, M. A. V., 2014 [Rullier, 2010 ; Nicorescu, I., Loisel, C., Riaublanc, A., Vial, C., Djelveh, G., Cuvelier, G. \& Legrand, J., 2009). Recent works on emulsions containing $30 \% \mathrm{w} / \mathrm{w}$ of milk fat showed that aggregates composed of casein micelles (CM) and whey proteins (WP), called mixed aggregates, are able to promote oil droplets interconnection, texturizing then emulsions (Surel, C., Foucquier, J., Perrot, N., Mackie, A., Garnier, C., Riaublanc, A. \& Anton, M., 2014). Evidence has been given that competitive adsorption during homogenization of milk protein stabilized emulsions leads to the formation of a heterogeneous complex layer at the interface. These interfaces are composed of native proteins (WP and CM) and modified aggregates like whey proteins aggregated alone or with casein micelles. They showed that the CM/WP ratio combined with their structure allowed the formation of different interfacial layers (from thin to thick and heterogenous) leading to various textures of emulsions which could be modeled (Descamps, E., Perrot, N., Trelea, L. C., Gaucel, S., Riaublanc, A., Mackie, A. \& Lutton, E., 2014). When the proteins are native $\left(60^{\circ} \mathrm{C}\right)$, the emulsions are liquids, the droplets being not connected. The same behavior is observed with the emulsions containing $80 \% \mathrm{CM}$ heated at $80^{\circ} \mathrm{C}$. When the proteins are heated at $80^{\circ} \mathrm{C}$ and with low content of $\mathrm{CM}$, the interface is covered by aggregated WP and the emulsions are gelled, the same case being observed when the WP are aggregated on the CM (between $26 \%$ and $50 \% \mathrm{CM}$ ). In the intermediate case (between $19 \%$ and $26 \% \mathrm{CM}$ ), the interface is composed of WP and 
$\mathrm{CM}$ and the emulsions are only structured. Three kinds of rheological behavior and four different interfacial structures were characterized (Fig. 3). In the first group, the emulsions were liquid, showing no connections between droplets. In the second group the emulsions were structured, the droplets being weakly connected by WP aggregated. In the third group the emulsions gelled, the droplets being connected by CM/WP complex or in other case by aggregated WP.
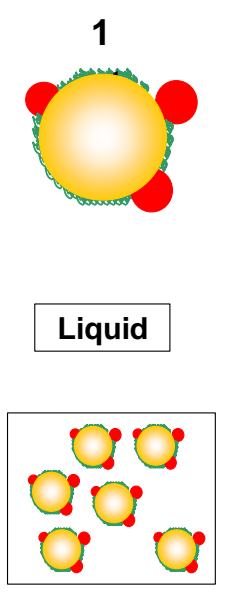

2

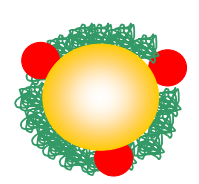

Structured

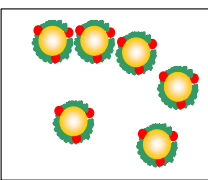

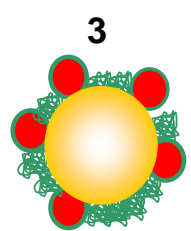

Gel

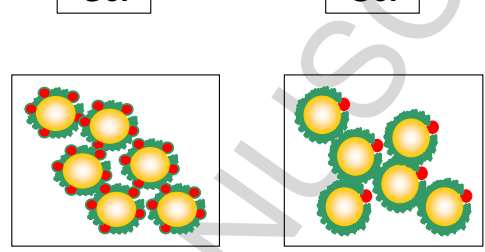

4

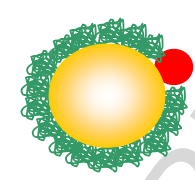

Gel

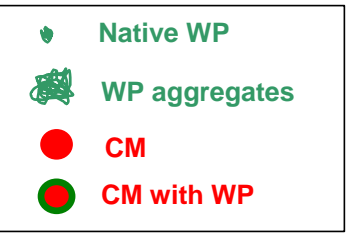

Fig. 3.

Summary scheme of the structure of interface and the texture of emulsions (Surel, C., Foucquier, J., Perrot, N., Mackie, A., Garnier, C., Riaublanc, A. \& Anton, M., 2014)

Based on these results, Loiseleux et al. (2017) investigated the texture of low fat dairy emulsions stabilized by a mixture of Whey Protein Aggregates (WPA) $(2$ or $3 \% \mathrm{w} / \mathrm{w})$ and $0.1 \%(\mathrm{w} / \mathrm{w})$ of native whey protein (Loiseleux, T., Garnier C., Beaumal V., Croguennec T., Guilois S., Jonchère C., RolandSabaté A., Anton M. \& Riaublanc, A., 2017). Surprisingly, these low oil content emulsions texturize over time without additives through two mechanisms: the first one occurs during homogenization and concerns the bridging flocculation between droplets by WPA and the second one appears during storage and corresponds to the formation of a protein-lipid network leading to emulsion gelling. Molecular interactions and density of the protein-lipid network depends on storage temperature and 
WPA concentration. Moreover, rheological properties of these emulsions are able to recover after shearing that could be very interesting for food application perspectives.

Some assemblies stabilized by proteins exist naturally in raw materials. It is the case of Low Density Lipoproteins (LDL), extracted from egg yolk, that are spherical nanoparticles ( $30 \mathrm{~nm}$ ) with a lipid core surrounded by a monofilm of proteins and phospholipids (Anton, M., Martinet, V., Dalgalarrondo, M., Beaumal, V., David-Briand E. \& Rabesona, H., 2003). It appears that LDL can serve as vectors of surfactant constituents (proteins and phospholipids) that could not be soluble in water, until the interface where they can adsorb (Martinet, V., Beaumal, V., Dalgalarrondo, M. \& Anton, M., 2002). Furthermore, evidence has been given, comparing interfacial behavior of LDL and liposomes (double phospholipid layer not containing proteins), that the proteins situated on the LDL surface trigger LDL disruption mechanism by their initial anchorage (Dauphas, S., Beaumal, V., Riaublanc, A. \& Anton, M., 2006; Martinet, V., Saulnier, P., Beaumal, V., Couthaudon, J.-L. \& Anton, M., 2003). Changing pH from 3 to 7 induced different structures of the film with 2D phase separation between phospholipids rich phase and protein rich phase which could widely modulate interactions between droplets in emulsions (Dauphas, S., Beaumal, V., Gunning, P., Mackie, A., Wilde, P., Vie, V., Riaublanc, A. \& Anton, M., 2007b; Dauphas, S., Beaumal, V., Gunning, P., Mackie, A., Wilde, P., Vie, V., Riaublanc, A. \& Anton, M., 2007a).

\section{Part 2. Food protein interactions and structure formation at high}

\section{concentrations}

CEPIA's researchers have contributed to the question of protein interactions at high concentrations by focusing on three specific systems: globular lysozyme protein solutions (Pasquier, C., Beaufils, S., Bouchoux, A., Rigault, S., Cabane, B., Lund, M., Lechevalier, V., Le Floch-Fouere, C., Pasco, M., Paboeuf, G., Perez, J. \& Pezennec, S., 2016), milk casein micelles dispersions (Bouchoux, A., 
Cayemitte, P. E., Jardin, J., Gésan-Guiziou, G. \& Cabane, B., 2009; Bouchoux, A., Debbou, B., GésanGuiziou, G., Famelart, M.-H., Doublier, J.-L. \& Cabane, B., 2009; Bouchoux, A., Gésan-Guiziou, G., Pérez, J. \& Cabane, B., 2010), wheat gliadins solutions (Boire, A., Menut, P., Morel, M.-H. \& Sanchez, C., 2015; Boire, A., Menut, P., Morel, M. H. \& Sanchez, C., 2013). These three systems have their own specificities which are described further in the text.

For most of these systems, protein-protein interactions were quantified by measuring the osmotic pressure of the solution at different concentrations. The osmotic pressure is the thermodynamics resultant of all the interactions in the system, and measures the resistance force that opposes deswelling, i.e. the cost of extracting solvent (water) molecules from the solution (LeNeveu, D. M., Rand, R. P. \& Parsegian, V. A., 1976). For colloidal and therefore protein solutions, this resistance originates from the interactions between the surfaces of the dispersed objects: the more the interactions are repulsive, the more it is difficult to bring the objects close to each other through solvent extraction. In the context of food science, the approach has the strong advantage to reproduce highly-concentrated conditions $(100-500 \mathrm{~g} / \mathrm{L})$ that are currently encountered in the industry, like for instance for the development of high-concentration protein formulations, or for the concentration of milk through membrane filtration (Bouchoux, A., Qu, P., Bacchin, P. \& GésanGuiziou, G., 2014).

The osmotic pressure was measured using the osmotic stress method (Parsegian, V., Rand, R., Fuller, N. \& Rau, D., 1986). Fig. 4 (A) gives a schematic view of an osmotic stress experiment. The protein dispersion is placed into a dialysis bag itself immersed in a reservoir of known osmotic pressure (a dispersion of Dextran or PEG). The dialysis bag is chosen so that only solvent and buffer molecules can diffuse through the membrane. At equilibrium (reached in about 4 weeks in a typical experiment), solvent has exchanged between the bag and the reservoir so that the chemical potential of water is the same in both compartment. Therefore, the osmotic pressure of the sample in the bag equals that of the reservoir, which yields to one point of the variation of the osmotic 
pressure with protein fraction. Using this method, it is usually possible to cover about 3 decades of osmotic pressures (from $\sim 1 \mathrm{kPa}$ to $\sim 1 \mathrm{MPa}$ ), achieving protein concentration up to $500-700 \mathrm{~g} / \mathrm{L}$ at the highest pressures.

The variation of the osmotic pressure with protein concentration is given in Fig. 4 (B-D) for the three protein systems studied by the INRA division, Science for Food and Bioproduct's researchers until now. We give below a brief description of these results, with additional information about the textural (rheological) and structural changes experienced by the solutions as concentration increases. It demonstrates how the diversity found in food proteins (including their assemblies) results in a rich range of behaviors in concentrated systems.

\section{A Principle of osmotic stress}

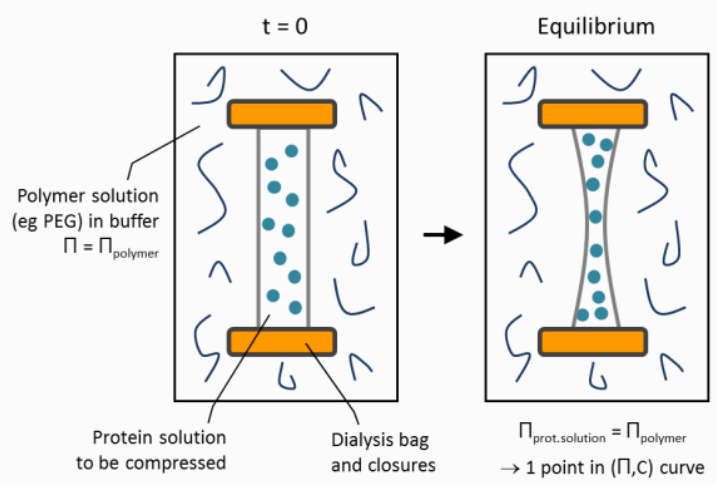

$\phi$, eq. volume fraction

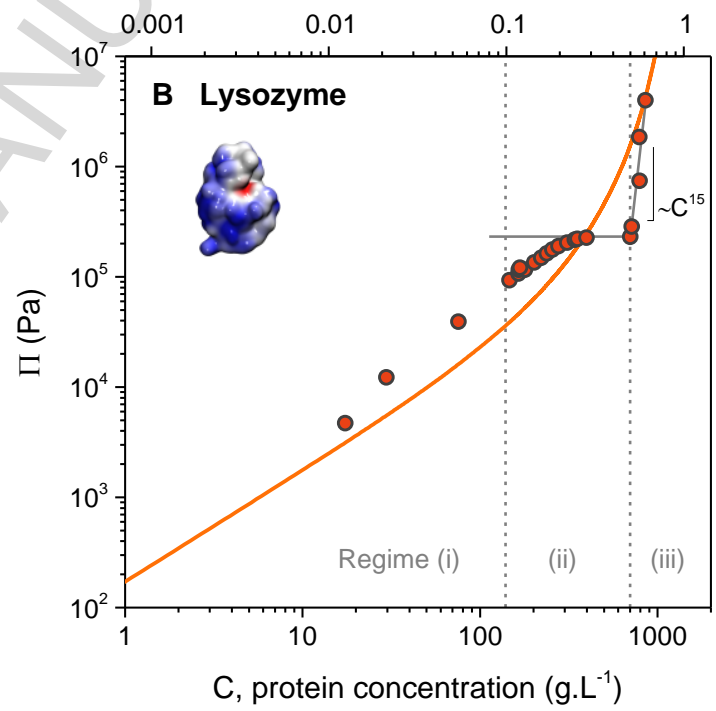



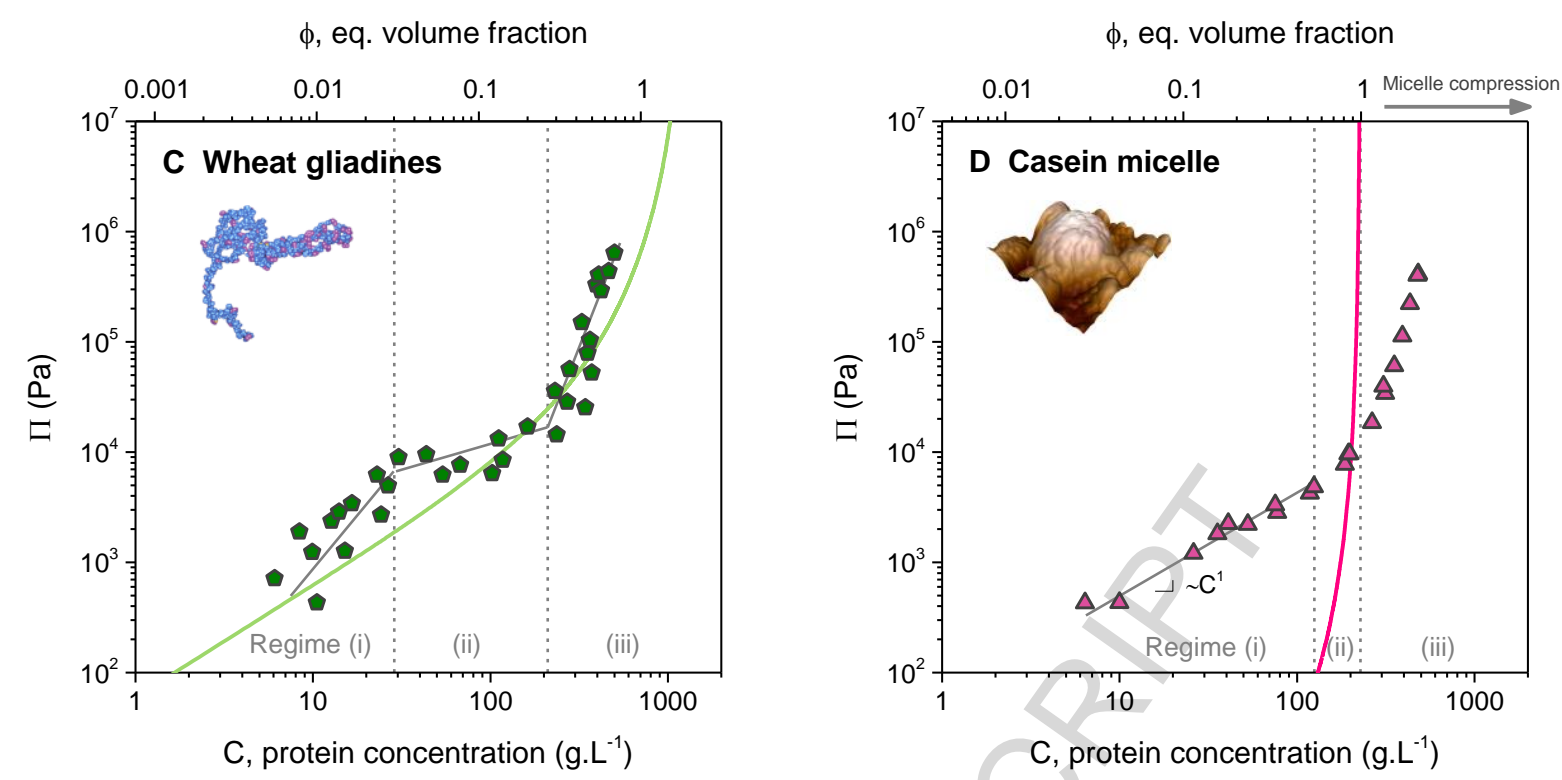

Fig. 4.

Osmotic compression of protein solutions. The principle of the technique is given in (A). Fig.s (B), (C), and $(D)$ give the evolution of the measured osmotic pressure of three different protein solutions as a function of protein concentration C and volume fraction $\phi$ : Iysozyme (B), wheat gliadins (C), casein micelle (D). In (D), $\phi$ is calculated using the volume occupied by the casein micelles and thus takes into account the volume of water they contain (about $85 \%$ of their total volume in the native state). The full lines are guides for the eye. The vertical dotted lines are the frontiers of the compression regimes discussed in the text.

\section{A. Lysozyme}

Lysozyme is a globular protein that has been well characterized since its discovery in 1922 (Fleming, A., 1922). Numerous studies have been conducted on lysozyme, in particular its self-association characteristics when concentrated or submitted to physicochemical changes (Cardinaux, F., Gibaud, T., Stradner, A. \& Schurtenberger, P., 2007; Gibaud, T., Cardinaux, F., Bergenholtz, J., Stradner, A. \& Schurtenberger, P., 2011). In a recent study, INRA division, Science for Food and Bioproduct's researchers measured the osmotic pressure of lysozyme solutions for ionic strengths up to $150 \mathrm{mM}$ 
using the osmotic stress method (Pasquier et al. 2016, Fig 4(B)). The data cover an exceptionally wide range of concentrations (10-1000 g.L-1) and osmotic pressures (5 kPa to about $4 \mathrm{MPa}$ ). Importantly, the process of concentrating the lysozyme solutions is shown to be totally reversible, i.e. a compressed lysozyme solution can be decompressed and compressed again without altering its physical state and position in the $\Pi / \phi$ curve. This suggests that the data obtained consist in the exact experimental counterpart of the thermodynamic equation of state of the system.

The osmotic pressure $\Pi$ vs. volume fraction $\phi$, reported on Fig. 4 (B) consists of (i) a dilute, gas-phase regime, (ii) a transition regime with a high-compressibility plateau, and (iii) a concentrated regime where the system is nearly incompressible with the osmotic pressure rising as the $15^{\text {th }}$ power of concentration. The structure of lysozyme molecules remains the same through the whole range of pressures and volume fractions, as established through Fourier Transform Infrared Spectroscopy (FTIR). The transition regime is caused by crystallization as revealed by small-angle $\mathrm{X}$-ray scattering (SAXS). A shift of the first two regimes is observed towards higher protein volume fractions upon decrease in the strength or range of the electrostatic interactions. This shift and the overall shape of the two first regimes are well captured by a model accounting for a steric repulsion, a short-range van der Waals attraction and a screened electrostatic repulsion (Pasquier, C., Beaufils, S., Bouchoux, A., Rigault, S., Cabane, B., Lund, M., Lechevalier, V., Le Floch-Fouere, C., Pasco, M., Paboeuf, G., Perez, J. \& Pezennec, S., 2016).

\section{B. Wheat gliadins}

Wheat storage proteins are known to form under hydration and shear a viscoelastic matrix called gluten. It confers to wheat the properties to be processed into a large range of food products with widely contrasted textures. While the biochemical composition of wheat gluten has been widely studied, its structuring mechanisms remain speculative (Belton, P. S., 2005; Dahesh, M., Banc, A., Duri, A., Morel MH \& L., R., 2014; Dahesh, M., Banc, A., Duri, A., Morel MH \& L., R., 2016; Hamer, R. 
J., van Vliet, T. \& Lefebvre, J., 2005; MacRitchie, F., 2007). In a recent study, the osmotic compression of wheat gliadins, monomeric proteins, was investigated (Boire, A., Menut, P., Morel, M.-H. \& Sanchez, C., 2015). Gliadins differ from lysozyme and casein micelles in at least two criteria: they are anisotropic objects, which can be approximate to prolate ellipsoids with aspects ratio higher than 5 (Ang, S., Kogulanathan, J., Morris, G., KÃk, M. S., Shewry, P. R., Tatham, A. S., Adams, G. G., Rowe, A. J. \& Harding, S. E., 2010; Thomson, N. H., Miles, M. J., Popineau, Y., Harries, J., Shewry, P. \& Tatham, A. S., 1999), and they are a mixture of polydisperse proteins (Shewry and Halford, 2002). Again, three regimes of concentration are demonstrated on the osmotic pressure vs. volume fraction data reported on Fig.4 (C): (i) in the dilute regime, for $\phi<0.03$, the osmotic pressure is stronger than the one predicted for hard spheres of the same volume. Gliadins behave as repulsive colloids, characterized by a positive second virial coefficient which might arise from electrostatic and/or steric repulsion. In the second regime, for $0.03<\phi<0.16$, the osmotic pressure is quasi-constant beside strong variations in concentration. Here, the suspension is very easily compressed: gliadins become less repulsive and/or more attractive. Finally, in the last regime, for $\phi>0.16$, extracting water requires a large amount of energy: gliadins resist compression and are strongly interacting together via intermolecular interactions. By contrast with lysozyme, which form crystals, the gliadin solutions remain in a viscous but still liquid-like state up to the highest concentration (about $500 \mathrm{~g} / \mathrm{L}, \phi^{\sim 0.4 \text { ), a }}$ peculiar behavior suggesting a specific local organization, which deserves now further research.

\section{Casein micelle}

Casein micelles are complex macromolecular assemblies made of four distinct caseins, namely, as1, $\alpha s 2, \beta$, and $\kappa$-caseins, and $8 \%$ in mass of phosphate and calcium ions. Casein micelles, with diameters ranging from 100 to $200 \mathrm{~nm}$, play a central role in the processing of milk, cheese, and most dairy products. Their structural and physical properties have been studied extensively over the last 50 years, however their structure is still a puzzle and is continuously the subject of debates among the 
scientific community (Holt, C., Carver, J. A., Ecroyd, H. \& Thorn, D. C., 2013; Horne, D. S., 2006; Qi, P. X., 2007). The osmotic pressure vs. volume fraction data for casein micelle dispersions is reported on Fig. 4 (D), also consists of three regimes (Bouchoux, A., Cayemitte, P. E., Jardin, J., Gésan-Guiziou, G. \& Cabane, B., 2009). In the dilute regime (i), $\Pi$ is proportional to the casein concentration. In this concentration range, casein micelles are well separated and rarely interact: their number density is very small, and $\Pi$ is dominated by the contribution of small residual peptides dissolved in the aqueous phase. The transition regime (ii) starts when micelles begin to interact through their surface covered by $\kappa$-casein brushes and ends when the micelles are forced to get into direct contact with each other. At the end of this regime, the dispersions behave like a coherent soft solid that does not fully redisperse when osmotic stress is released. Finally, the concentrated regime (iii) is reached when compression removes water from the micelles, which increases the fraction of micelles that are irreversibly linked to each other. In this last regime the $\Pi$ profile obeys models based on the free volume concepts and that consider the micelles to be made of a heterogeneous network containing dense regions.

Unlike lysozyme, casein micelles do not crystallize upon increasing concentration. However, the dispersions gradually turn into "gels" or soft solid as concentration increases above the concentration of random-close packing, estimated at $\mathrm{Cmax}=178 \mathrm{~g} / \mathrm{L}(\Phi=0.78)$ (Bouchoux, A., Debbou, B., Gésan-Guiziou, G., Famelart, M.-H., Doublier, J.-L. \& Cabane, B., 2009). SAXS data indicate that this compression is non affine, i.e. some parts of the micelle collapse whereas other parts resist to deformation, a behavior consistent with the osmotic pressure data and with the view of a sponge-like casein micelle having a hierarchical internal structure (Bouchoux, A., Gésan-Guiziou, G., Pérez, J. \& Cabane, B., 2010). 


\section{Part 3. Heteroprotein complex coacervation}

Heteroprotein complex coacervation (HPCC) is a special case of liquid-liquid phase separation because the liquid dense phase is composed by at least two different proteins. Additional specificities compared to other well-studied complex coacervation systems lie in that HPCC is observed in a very narrow $\mathrm{pH}$ range, at much lower ionic strength and for very specific stoichiometry. During the last decade, the INRA division Science for Food and Bioproduct's researchers developed research programs around the fundamental and applied aspects of complex coacervation in heteroprotein systems. Working on several binary systems, we have conducted several multiscale researches to highlight the mechanism behind HPCC as well as the potential application of formed coacervates.

At molecular level, the use of combined techniques, i.e. nuclear magnetic resonance (NMR), isothermal titration calorimetry (ITC), fluorescence anisotropy, molecular modelling allowed access to the initial interaction parameters. Whatever the binary system, electrostatic interactions are shown to be the main driving forces for the formation of heteroprotein complexes (Peixoto, P. D. S., Tavares, G. M., Croguennec, T., Nicolas, A., Hamon, P., Roiland, C. \& Bouhallab, S., 2016; Salvatore, D. B., Duraffourg, N., Favier, A., Persson, B. A., Lund, M., Delage, M.-M., Silvers, R., Schwalbe, H., Croguennec, T., Bouhallab, S. \& Forge, V., 2011). ITC gives information on the thermodynamic parameters of the interaction $\left(K_{a}, n, \Delta H\right)$ between oppositely charged proteins. We determined one binding site on $\alpha$-lactalbumin ( $\alpha$-LA) for lysozyme (Nigen, M., Croguennec, T., Renard, D. \& Bouhallab, S., 2007) and two unequal binding sites on lactoferrin (LF) for $\beta$-lactoglobulin ( $\beta$-LG) (Tavares, G. M., Croguennec, T., Hamon, P., Carvalho, A. F. \& Bouhallab, S., 2015). The $K_{a}$ value of the interaction between LYS and $\alpha$-LA was further confirmed by ${ }^{1} \mathrm{H}-{ }^{15} \mathrm{~N}$ NMR studies using labelled proteins (Salvatore, D. B., Duraffourg, N., Favier, A., Persson, B. A., Lund, M., Delage, M.-M., Silvers, R., Schwalbe, H., Croguennec, T., Bouhallab, S. \& Forge, V., 2011). Although electrostatic interactions are the driving forces, charge compensation is not sufficient to observe heteroprotein coacervation, meaning that the HPCC does not result from the simple electrostatic protein charge screening but 
rather from the association of heteroprotein complexes with specific structure and stoichiometry. Protein stoichiometry can be estimated by direct protein quantification in the coacervates (Desfougères, Y., Croguennec, T., Lechevalier, V., Bouhallab, S. \& Nau, F., 2010; Nigen, M., Croguennec, T., Renard, D. \& Bouhallab, S., 2007). Interestingly, when the size of the oppositely charged protein is similar (e.g. LYS and $\alpha$-LA; ovalbumin OVA and avidin AVI), the pH of maximal coacervation occurs at mid-way between the $\mathrm{pl}$ of the proteins and the protein molar ratio in the coacervates is 1 . In contrast, when the size of the protein is significantly different, the protein molar ratio in the coacervate deviate from 1 . Identification of the amino acid residues in interaction on each protein allowed us to confirm that the uneven charge distribution on the protein surfaces governs the orientational alignment of both proteins and influences their relative proportion in the formed heteroprotein complexes (Peixoto, P. D. S., Tavares, G. M., Croguennec, T., Nicolas, A., Hamon, P., Roiland, C. \& Bouhallab, S., 2016; Salvatore, D. B., Duraffourg, N., Favier, A., Persson, B. A., Lund, M., Delage, M.-M., Silvers, R., Schwalbe, H., Croguennec, T., Bouhallab, S. \& Forge, V., 2011). Combining the results from different binary systems, we evidenced that charge and size compensations between the oppositely charged proteins are required to form heterooligomers, the primary units of the coacervates (Desfougères, Y., Croguennec, T., Lechevalier, V., Bouhallab, S. \& Nau, F., 2010). Under optimal conditions, coacervation occurs following special adjustment of these oligomers into small complexes. We identified different heterooligomers: dimers for holo- $\alpha$-LA/LYS, trimers for OVA/LYS, tetramers for apo- $\alpha$-LA/LYS and for BSA/LYS, pentamers for $\beta$-LG/LF.

Microscopic technics were used to investigate macroscopic scale. During coacervation, the time course of droplet formation depends on the initial protein concentration. Using fluorescence labelled protein and confocal microscopy, we followed the progressive formation of protein droplets of 3-5 um over time (Nigen, M., Le Tilly, V., Croguennec, T., Drouin-Kucma, D. \& Bouhallab, S., 2010). The droplets progressively become larger and sediment on ageing forming a viscous phase. The growth mechanism is indicative of a mechanism of growth by collision and fusion (coalescence) of small 
droplets in larger ones (Nigen, M., Le Tilly, V., Croguennec, T., Drouin-Kucma, D. \& Bouhallab, S., 2010; Salvatore, D., Croguennec, T., Bouhallab, S., Forge, V. \& Nicolai, T., 2011).

HPCC is a reversible phenomenon involving at least two equilibria: one between the oppositely charged proteins and the heteroprotein complexes and the other one between the heteroprotein complexes in the dense and dilute phases. The dynamics and the relative abundance of the molecular species in the coacervates were investigated using a combination of FRAP, molecular modelling and solid state NMR (Peixoto, P. D. S., Tavares, G. M., Croguennec, T., Nicolas, A., Hamon, P., Roiland, C. \& Bouhallab, S., 2016). We demonstrated for the first time the compositional heterogeneity of the coacervate phase with a co-existence of at least three types of molecular entities. An elegant experiment was performed to illustrate protein dynamics at another scale between dilute and dense phase in the case of apo $\alpha$-LA/LYS system (Nigen, M., Le Tilly, V., Croguennec, T., Drouin-Kucma, D. \& Bouhallab, S., 2010). The coacervates were formed with a mixture of unlabelled apo $\alpha$-LA and FITC-labelled LYS, then RBITC-labelled LYS was added to the coacervate solution. The gradual shift from green to orange-red droplets under confocal microscope over time illustrated visually a continuous dynamic protein exchange between the two liquid-liquid phases.

As theoretically expected, HPCC is sensitive to environmental conditions and is affected by several factors. The $\mathrm{pH}$ determines the overall charge of the proteins and the size of the charged patches on their surfaces. A shift of $\mathrm{pH}$ on both side of optimal conditions reduces or inhibit coacervation (Tavares, G. M., Croguennec, T., Hamon, P., Carvalho, A. F. \& Bouhallab, S., 2015). Compared to other complex coacervation, HPCC is highly sensitive to ionic strength. In our studies, $\alpha$-LA/LYS is the most resistant binary system to ionic strength as coacervation still occurs at salt concentration as high as $50 \mathrm{mM}$. For all other systems, no coacervation was detected above an ionic strength higher than 25 mM. However, once formed HPCC are stable to ionic strength as high as $200 \mathrm{mM}$ (Nigen, M., Croguennec, T. \& Bouhallab, S., 2009). We have to date many elements supporting the paramount 
importance of surface charge and surface anisotropy (Nigen, M., Le Tilly, V., Croguennec, T., DrouinKucma, D. \& Bouhallab, S., 2009; Salvatore, D. B., Duraffourg, N., Favier, A., Persson, B. A., Lund, M., Delage, M.-M., Silvers, R., Schwalbe, H., Croguennec, T., Bouhallab, S. \& Forge, V., 2011). The crucial role of protein surface charge for HPCC was highlighted in the case of $\beta$-LG/LF system, as LF exhibits preferential interaction for $\beta$-LG variant $A$ that exhibits one more negative charge compared to $\beta-L G$ variant $\mathrm{B}$. We showed the dependence of the optimal $\mathrm{pH}$ for coacervation on $\beta$-LG variant with very high coacervation yield with the more acidic variant (Tavares, G. M., Croguennec, T., Hamon, P., Carvalho, A. F. \& Bouhallab, S., 2015).

Owing to their economic and environmental benefits, the use of plant proteins is also a matter of subject for INRA, Science for Food and Bioproduct 's Division. In this sense, we have undertaken HPCC in a mixture of animal ( $\beta$-casein) and plant (napin) proteins (Schwartz, J.-M., Solé, V., Guéguen, J., Ropers, M.-H., Riaublanc, A. \& Anton, M., 2015). Although the term "coacervation" was not used, the aggregation/assembly between the two oppositely charged proteins is controlled by $\mathrm{pH}$, ionic strength and protein mass ratio in an independent manner. Addition of salt or chelating agents of divalent cations suppressed the aggregation process. The formation of $\beta$-casein and napin assemblies can be thus controlled by adjusting the concentration, the salinity of the media and/or by introducing a complexing agent.

\section{Part 4. Examples of innovative applications}

Three examples of innovative studies of Science for Food and Bioproduct's INRA Division teams around new uses of proteins in food and non-food applications will be developed in this part. 


\section{A. Fibrous proteins from animal by-products}

By-products arising during animal slaughtering for human consumption are a source of valuable proteins having diversified features and applications in biomedicine, biomaterials, pharmaceuticals and food (Ferraro, V., Anton, M. \& Santé-Lhoutellier, V., 2016; Liu, D., Nikoo, M., Boran, G., Zhou, P. \& Regenstein, J. M., 2015). They are also a source of "cryptides", bioactive peptides (2 - 30 residues) hidden within the sequence of the parent protein. They can play a special role in the major human disease known as metabolic syndrome, which clusters insulin resistance, abnormalities in lipids metabolism, arterial hypertension and obesity (Ben Henda, Y. \& Bordenave-Juchereau, S., 2014).

Animal by-products account for 40 to $60 \%$ of the animal weight and are mainly represented by the scleroproteins (fibrous proteins) collagen, elastin and keratin, one of the three groups of proteins known, along with globular and membrane ones (Ferraro, V., Anton, M. \& Santé-Lhoutellier, V., 2016). They have peculiar and distinct characteristics and structures reported on Fig. 5.

Collagen, elastin and keratin shape the form, confer structure, resistance and motility and provide the extra-cellular environment for metabolic pathways. They structure living organisms in the animal kingdom as polysaccharides do in the plant one (Ferraro, V., Anton, M. \& Santé-Lhoutellier, V., 2016). Indeed the exclusive functional and bioactive properties that collagen, elastin and keratin show in virtue of their molecular structures open to the possibility to replace synthetic compounds with more performant, human-compatible and biodegradable ones (Daamen, W. F., Veerkamp, J. H., van Hest, J. C. M. \& van Kuppevelt, T. H., 2007; Filipello Marchisio, V., 2000; Shoulders, M. D. \& Raines, R. T., 2009). The intrinsic complexity and capability of natural collagen, elastin and keratin to interact with many other proteins and biomolecules make possible the treatment of numerous diseases, a potential which still remains to be achieved through heterologous and synthetic ways of production (Daamen, W. F., Veerkamp, J. H., van Hest, J. C. M. \& van Kuppevelt, T. H., 2007; Ferraro, V., Anton, M. \& Santé-Lhoutellier, V., 2016; Filipello Marchisio, V., 2000; Shoulders, M. D. \& Raines, R. T., 2009). 
Collagen and elastin are the major constituents of connective tissue, both are crucial for locomotion. Collagen is the main constituent of bones, tendons and skin. Ligaments, lungs and aorta have elastin in a strong network with collagen (Ferraro, V., Anton, M. \& Santé-Lhoutellier, V., 2016; Liu, D., Nikoo, M., Boran, G., Zhou, P. \& Regenstein, J. M., 2015; Shoulders, M. D. \& Raines, R. T., 2009). Keratin is the key component of the integumentary systems; it provides waterproof, thermal regulation, protection against mechanical shock and infections; it is a sensor for pain and pressure (Ferraro, V., Anton, M. \& Santé-Lhoutellier, V., 2016).

Keratins act like rubber and represent an ecological problem for the high resistance to degradation in the environment (Filipello Marchisio, V., 2000). Under thermodynamic equilibrium, collagen, elastin and keratin spontaneously self-assemble into well-defined networks which are a topic of increasing attention from a scientific and applicative point of view (Daamen, W. F., Veerkamp, J. H., van Hest, J. C. M. \& van Kuppevelt, T. H., 2007; Liu, D., Nikoo, M., Boran, G., Zhou, P. \& Regenstein, J. M., 2015). Biocompatible, biodegradable and mimetic constructs, such as scaffolds for cells adhesion, skin and vascular substitutes, as well as macro-, micro- and nanocapsules for drugs delivery could be obtained by the spontaneous arrangement and/or inducted crosslinking of collagen, elastin and keratin recovered from animal by-products. Also, the characteristics rheological and functional properties could allow to conceive emulsifiers (especially in the view of fat and starch reduction), edible casings for meat products, biodegradable packaging as well as functionalization of textiles (Ferraro, V., Anton, M. \& Santé-Lhoutellier, V., 2016; Liu, D., Nikoo, M., Boran, G., Zhou, P. \& Regenstein, J. M., 2015).

In spite of the numerous articles published on the recovery of collagen from animal by-products ) the contribution of factors such as ultrasounds, pressure and magnetic field on the yield and structure of collagen has not been evaluated yet (Ferraro, V., Anton, M. \& Santé-Lhoutellier, V., 2016. Also, interaction of collagen with the non-collagenous proteins and mineral phase of the tissue during 
extraction remains to be assessed since those components can have great influence on collagen selfassembly, functionality and bioactivity.

Concerning elastin, this protein is a highly insoluble and stable polymer with an uncommon amino acids composition, about $75 \%$ hydrophobic residues (Gly, Val, Ala); it is the longest lasting protein in vertebrates (140 years). A distinguishing feature of elastin is also its resistance to high temperature and $\mathrm{pH}$ that usually denature many proteins (Daamen, W. F., Veerkamp, J. H., van Hest, J. C. M. \& van Kuppevelt, T. H., 2007). Heating the tissue and use strong alkali in order to purify elastin from nonelastinous material like collagen and fat could be used to obtain whole, however insoluble and not pure elastin.

Finally, Keratin is easily available and abundant protein in poultry feathers, wool and pig bristles, of which it represents $90 \%$ by weight (Ferraro, V., Anton, M. \& Santé-Lhoutellier, V., 2016). Among all, feathers keratins are the most complex however the most interesting for application in biomaterials, and also technical materials, due to their hardness. Anionic surfactants, proteases and reducing agents have great potential to break the strong disulphide bonds which stabilise the keratin quadruple helix. Few available researches have demonstrated that oxidative extraction, with peracetic acid or hydrogen peroxide for instance, could be used to obtain hygroscopic and watersoluble keratins which can be degraded relatively fast, in the order of days to weeks (Vasconcelos, A. \& Cavaco-Paulo, A., 2013). 

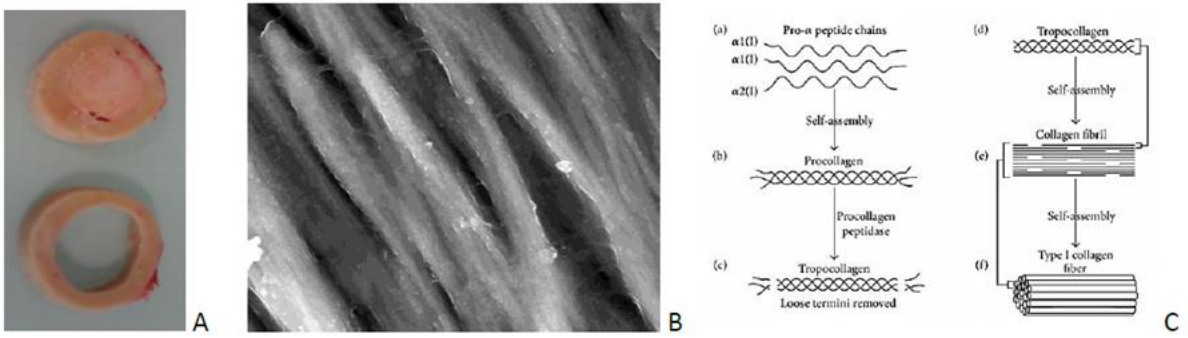

2 - Elastin
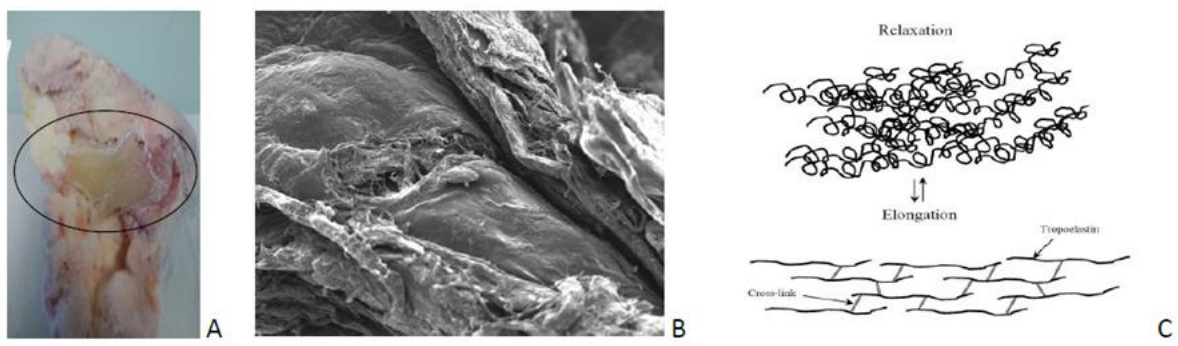

3- Keratin
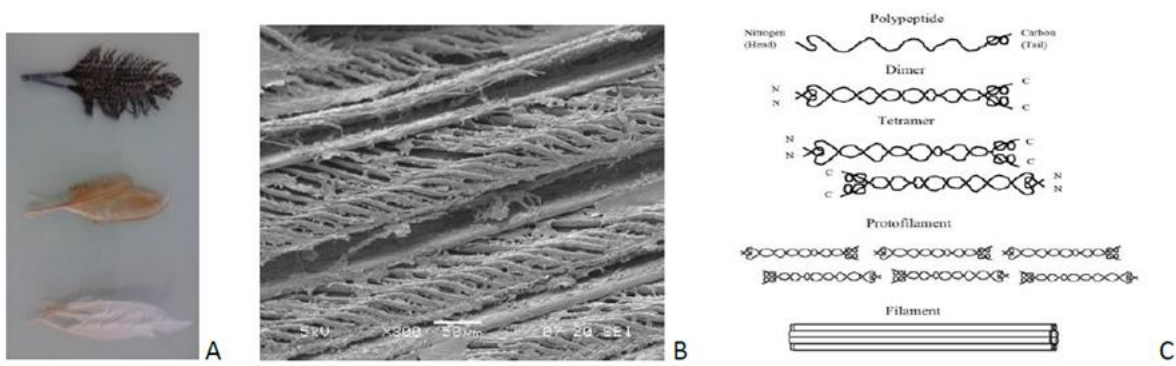

\section{Fig. 5.}

Fibrous proteins in animal by-products: collagen in cortical bone $(1 \mathrm{~A})$, elastin in ligaments (in the boundary) (2A) and keratin in feathers from different poultry breeds (3A); collagen, elastin and keratin self-assembly observed through Scanning Electron Microscopy (1B; $2 \mathrm{~B}$ and $3 \mathrm{~B}$ ) and respective molecular chains (1C, 2C and 3C) (Adapted from (Ferraro, V., Anton, M. \& Santé-Lhoutellier, V., 2016)).

\section{B. Legume proteins into pasta}

Cereal and legume are principal components of the Mediterranean diet, beneficial for the prevention of cardiovascular, type 2 diabetes, cancer diseases and obesity (Kastorini, C. M., Milionis, H. J., 
Goudevenos, J. A. \& Panagiotakos, D. B., 2010). The association of these two crops into a single food increases its protein content and be benefit from their complementary essential amino acid profiles (Laleg, K., Barron, C., Sante-Lhoutellier, V., Walrand, S. \& Micard, V., 2016). Considered as a staple and popular cereal food, pasta appears as an interesting model for such an association.

Up to 2010, the amount of legume flours incorporated to pasta did not exceed $35 \%$ as technological locks were encountered during mixing step with higher legume inclusion levels (Petitot, M., Boyer, L., Minier, C. \& Micard, V., 2010; Wood, J. A., 2009). The incorporation of $35 \%$ faba bean flour into wheat pasta increased its protein content from 13 to $19 \%$ and its lysine content from 21 to $39 \mathrm{mg} / \mathrm{g}$ of protein (Laleg, K., Barron, C., Sante-Lhoutellier, V., Walrand, S. \& Micard, V., 2016; Petitot, M., Barron, C., Morel, M.-H. \& Micard, V., 2010), keeping its low in vitro or in vivo glycemic index (Greffeuille, V., Marsset-Baglieri, A., Molinari, N., Cassan, D., Sutra, T., Avignon, A. \& Micard, V., 2015; Petitot, M., Barron, C., Morel, M.-H. \& Micard, V., 2010). Researches conducted in 2015-2016 by our teams itself or with the "technical research center - Finland" (W02016097328A1 and WO2015158960A1 patents, respectively), have suggested a technological issue to increase the level of legume flour inclusion up to $100 \%$ using a classical pasta extruder. Dried pasta produced according to W02016097328A1 patent are presented in Fig. 6A. The inclusion of $70 \%$ of legume into wheat pasta was demonstrated to increase its protein content to $21 \%$ and its lysine essential amino acid to $55 \mathrm{mg} / \mathrm{g}$ of protein. The pasta exclusively made of legume (100\% legume) contained 23 to $28 \%$ of protein (depending on the legume type) and were gluten free which could be of interest for celiac patients (Laleg, K., Cassan, D., Abecassis, J. \& Micard, V., 2016; Laleg, K., Cassan, D., Barron, C., Prabhasankar, P., \& Micard, V., 2016; Rosa-Sibakov, N., Heinio, R.-L., Cassan, D., Holopainen-Mantila, U., Micard, V., Lantto, R. \& Sozer, N., 2016; Sozer, A. N., Rosa-Sibakov, N. \& Sibakov, J., 2015).

The partial or total replacement of gluten by legume protein in pasta changed its structure which affected the delivery of its nutrients, mainly starch and proteins (Laleg, K., Barron, C., SanteLhoutellier, V., Walrand, S. \& Micard, V., 2016; Laleg, K., Cassan, D., Abecassis, J. \& Micard, V., 2016; 
Petitot, M., Barron, C., Morel, M.-H. \& Micard, V., 2010; Rosa-Sibakov, N., Heinio, R.-L., Cassan, D., Holopainen-Mantila, U., Micard, V., Lantto, R. \& Sozer, N., 2016). Pasta enriched with 35\% faba bean or split pea flour both presented, as $100 \%$ durum pasta, a continuous protein film surrounding swollen starch granules at microscopic scale (Petitot, M., Barron, C., Morel, M.-H. \& Micard, V., 2010). When increasing the level of legume (faba bean) its protein matrix appeared highly disrupted at microscopic scale (Laleg, K., Barron, C., Cordelle, S., Schlich, P., Walrand, S. \& Micard, V., 2016; Rajiv, J., Milind, Suresh, D.S., , Aashitosh, A. I. \& Venkateswara Rao, G., 2014). The thickness of protein network was not directly related to the amount of proteins inside pasta. For example, it was identical for faba bean enriched pasta (19\% protein) and wheat pasta (13\% protein) but thinner for split pea pasta (16\% protein) (Petitot, M., Barron, C., Morel, M.-H. \& Micard, V., 2010). The protein network appeared larger and denser in pasta containing $24 \%$ to $28 \%$ protein, produced exclusively from legume (faba bean, lentil and black gram) flours, than in wheat pasta (Laleg, K., Barron, C., Cordelle, S., Schlich, P., Walrand, S. \& Micard, V., 2016; Laleg, K., Cassan, D., Abecassis, J. \& Micard, V., 2016; Rosa-Sibakov, N., Heinio, R.-L., Cassan, D., Holopainen-Mantila, U., Micard, V., Lantto, R. \& Sozer, N., 2016) (Fig. 6B). According to Rosa-Sibakov et al. (Rosa-Sibakov, N., Heinio, R.-L., Cassan, D., Holopainen-Mantila, U., Micard, V., Lantto, R. \& Sozer, N., 2016) and to Laleg et al. (Laleg, K., Cassan, D., Abecassis, J. \& Micard, V., 2016) this larger and denser, even if disrupted, protein matrix helped to hider starch hydrolysis and to maintain the starch hydrolysis index of the $100 \%$ legume pasta close to that of wheat pasta.

In comparison to wheat pasta, the proteins in $35 \%$ faba bean enriched pasta presented a less flexible secondary structure characterized by a higher amount of $\beta$-sheet structures ((Laleg, K., Barron, C., Sante-Lhoutellier, V., Walrand, S. \& Micard, V., 2016). This higher level of hydrophobic $\beta$-sheet conformations could be susceptible to decrease the accessibility of hydrolysis sites to proteases in autoclaved legume proteins (Carbonaro, M., Maselli, P. \& Nucara, A., 2012). However, in cooked 35\% faba bean enriched pasta the higher amount of $\beta$-structures did not reduce the percentage of in vitro 
hydrolyzed proteins by pepsin and pancreatin (Laleg, K., Barron, C., Sante-Lhoutellier, V., Walrand, S. \& Micard, V., 2016), meaning that structural parameters others than the secondary conformation of protein could be involved in their digestibility.

The proteins were less covalently linked in $35 \%$ faba bean or split pea enriched pasta $(69 \%$ of covalently linked protein) (Fig. 6C) than in wheat pasta ( $84 \%$ of covalently linked protein) (Petitot, M., Barron, C., Morel, M.-H. \& Micard, V., 2010). This weakening in pasta protein network structure at supramolecular scale was more pronounced when gluten proteins were entirely replaced by legume proteins (faba bean, lentil of black-gram). Indeed, in $100 \%$ legume pasta, most proteins (68 to $88 \%$ ) were weakly linked (Laleg, K., Cassan, D., Abecassis, J. \& Micard, V., 2016). This weakening in protein matrix is related to the dilution of gluten network by the albumins and globulins from legume flour (Petitot, M., Barron, C., Morel, M.-H. \& Micard, V., 2010), which contain low cysteines (Carbonaro, M., Cappelloni, M., Nicoli, S., Lucarini, M. \& Carnovale, E., 1997) able to interact to form covalent disulfide bound. The in vitro digestibility of the protein network of the faba bean enriched pasta ( $35 \%$ to $100 \%$ ), less covalently linked than gluten network of wheat pasta, was up to $23 \% \%$ higher (Fig. $6 \mathrm{C}$ ) probably due to a higher accessibility of proteases Some studies reported the effect of the incorporation of low level of legume flours $(<30 \%)$ in pasta on the in vivo protein digestibility. Rats eating pasta enriched with $10 \%$ lupin flour vs wheat pasta showed an identical true digestibility of protein (Torres, A., Frias, J., Granito, M., Guerra, M. \& Vidal-Valverde, C., 2007). A corn-based spaghetti enriched with $30 \%$ broad bean (Vicia faba) experienced at the opposite, in comparison to the non-enriched corn pasta, a $11 \%$ lower true digestibility of protein but a $60 \%$ and a $80 \%$ higher net protein utilization and biological value, respectively, thanks to the complementary essential amino acid profile of cereals and legumes (Giménez, M. A., Drago, S. R., Bassett, M. N., Lobo, M. O. \& Sammán, N. C., 2016).

Some in vivo studies performed on both rats and humans suggested that legume (soy) proteins exhibits a higher intestinal transit rate than milk protein (Fouillet, H., Mariotti, F., Gaudichon, C., Bos, 
C. \& Tome, D., 2002; Hara, H., Nishikawa, H. \& Kiriyama, S., 1992), permitting a rapid absorption and delivery of amino acid in the peripheral circulation (Bos, C., Metges, C. C., Gaudichon, C., Petze, K. J., Pueyo, M. E., Morens, C., Everwand, J., Benamouzig, R. \& Tome, D., 2003). A rapidly digested protein would be highly beneficial for elderly people suffering from muscle weight loss (Dangin, M., Guillet, C., Garcia-Rodenas, C., Gachon, P., Bouteloup-Demange, C., Reiffers-Magnani, K., Fauquant, J., Ballevre, O. \& Beaufrere, B., 2003), as it induces a rapid and a high increase in aminoacidemia required to stimulate the muscle protein synthesis (Boirie, Y., Dangin, M., Gachon, P., Vasson, M. P., Maubois, J. L. \& Beaufrere, B., 1997). According to this criterion, it seems promising to enrich pasta with legume flours. However, in-vivo studies on animal and human models have to be performed to confirm whether pasta enriched with high amount of legume ( $\geq 35 \%)$ maintains a high protein digestibility and retention, a rapid amino acid delivery, and a rapid protein synthesis on young but also on old subjects. These researches are currently conducted in collaboration with the Human Nutrition Research Team of INRA Clermont-Ferrand.

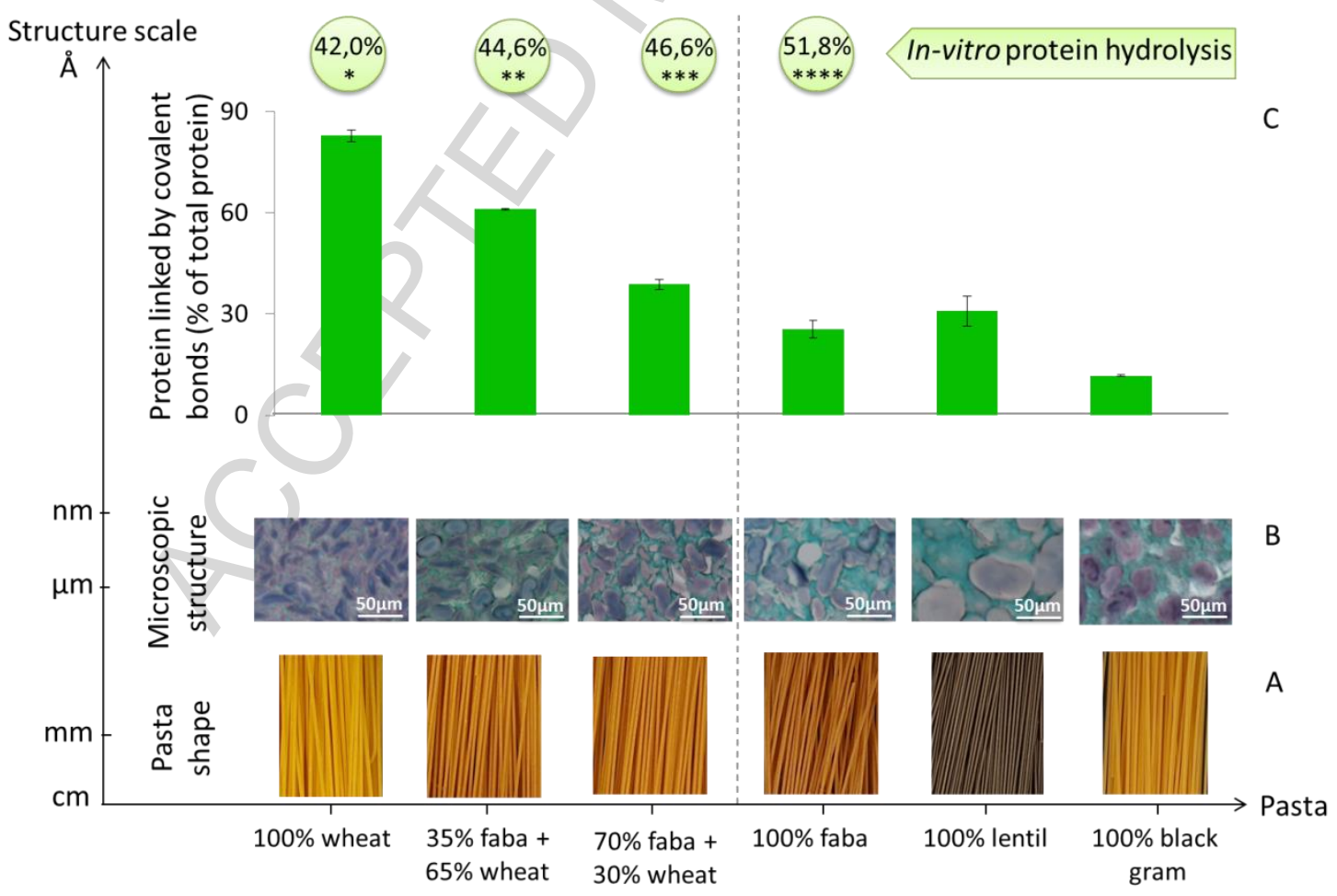

Fig. 6. 
Multi-scale pasta structure. A, the macroscopic scale: dried pasta shape; $B$, the microscopic scale: Cooked pasta microstructure; and C, the molecular scale: the percentage of covalently linked protein (disulfide and others) in cooked pasta. In-vitro protein hydrolysis of cooked pasta (\% of total protein) is indicated in green bubbles. Bubbles wearing different number of asterisks are significantly different. Adapted from (Laleg, K., Barron, C., Cordelle, S., Schlich, P., Walrand, S. \& Micard, V., 2016; Laleg, K., Barron, C., Sante-Lhoutellier, V., Walrand, S. \& Micard, V., 2016; Laleg, K., Cassan, D., Abecassis, J. \& Micard, V., 2016)

\section{Encapsulation of nutrients as potential application of heteroprotein complex}

\section{coacervates}

Complex coacervation can be used as encapsulation technology to ensure the protection, stabilization and/or controlled delivery of specific bioactives such as flavors, antioxidants, vitamins, fatty acids, peptides, minerals, etc. Milk proteins, designed as capsules or structured with other biopolymers, constitute a universal example for encapsulation purposes (Tavares, G. M., Croguennec, T., Carvalho, A. F. \& Bouhallab, S., 2014). We have studied the ability of $\beta$-LG/LF to entrap efficiently a hydrophilic molecule, e.g. vitamin B9 (B9). The first step was to determine the efficient conditions for complex coacervation in the presence of B9 (Fig. 7). We showed that the formation of vitamin B9heteroprotein coacervates occurs at specific protein concentration range (Chapeau et al. 2016). The recovered dense phase (vitamin B9-whey protein coacervates) is highly concentrated in proteins $(\sim 300 \mathrm{~g} / \mathrm{kg})$ and shows an interesting biocarrier efficiency of 4 to $10 \mathrm{~g} \mathrm{B9} / \mathrm{kg}$ coacervates. The vitamin B9-whey protein coacervates is stable and shows interesting potentiality to protect the vitamin B9 toward photodegradation (unpublished). Now, a challenging part is to study the scaling-up of HPCC loaded bioactives from laboratory and bench scales to pilot scale. Also, the conditions for a controlled release of bioactives from heteroprotein coacervates during their digestion have to be further investigated. These studies are currently undertaken. 
Until today, HPCC is a largely unexplored phenomenon. We are convinced that it can bring mechanistic information about protein assemblies useful for all areas of biology. They are also promising objects for various applications including, encapsulation, change of food texture and formation of biocompatible protein films. This fascinating research topic becomes of high interest for food scientists as several research groups start to publish on HPCC.

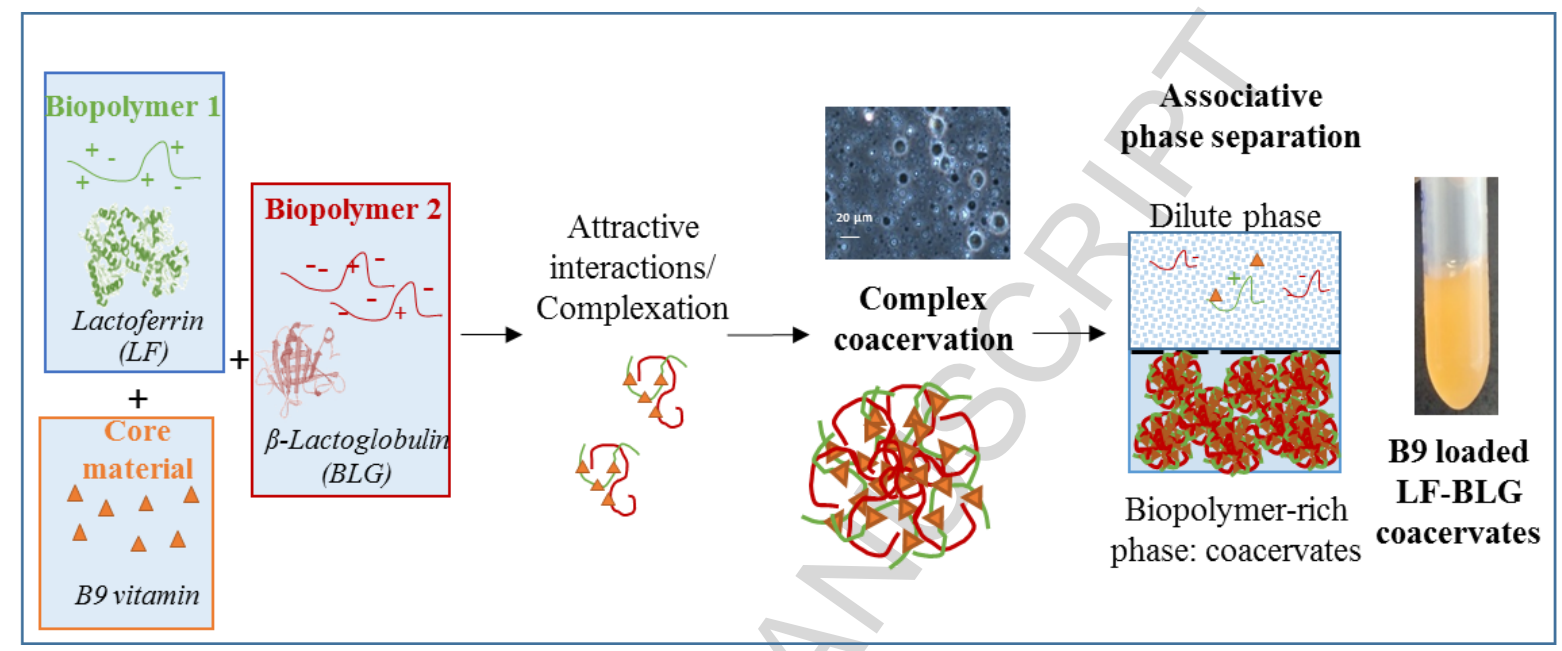

Fig. 7. Encapsulation of a hydrophilic compound (vitamin B9) by heteroprotein complex coacervates.

\section{Conclusion}

Animal or plant-based proteins are present in a wide variety of processed and non-processed food products. The nature and concentrations of the proteins involved vary massively from one product to another but in many of these products, the protein interactions play a central role in determining the final structure and properties of the product. In the past 15 years Science for Food and Bioproduct's researchers have led soft matter approaches to establish the link between food protein interactions, phase transitions and structural properties especially at the interfaces, in condensed state, or in complex coacervation conditions, in view to build functional structures. 
Now, in a context of demographic and food transitions, environmental and energy constraints, and links between these factors and public health, the challenge of Science for Food and Bioproduct's teams is to integrate food systems in all their dimensions from production to end use taking into account sourcing, production method, composition / structure, processing methods, digestive deconstruction, by-products, ... to reach to sustainability criteria. In this way alternative sources of food proteins (plant, algae, insect) and by-product valorization will require the development of extraction strategies, the screening and design of functional mixed protein assemblies, and the understanding of aggregation and self-assembly of proteins to generate functional assemblies taking into account the physiological conditions and the physics of condensed media. All the previous works of Science for Food and Bioproduct's INRA Division described in this chapter constitute solid foundations to address these future challenges.

Author's contributions: Introduction: M. Anton, Part 1: M. Anton, V. Lechevallier, S. Pezennec, A. Riaublanc, Part 2: A. Boire, A. Bouchoux, P. Menut, S. Pezennec, Part 3: S. Bouhallab, T. Croguennec, Part 4: S. Bouhallab, A-L. Chapeau, V. Ferraro, K. Laleg, V. Micard, V. Santé-Lhoutellier, Conclusion: M. Anton, D. Renard

\section{References}

Ang, S., Kogulanathan, J., Morris, G., KÃk, M. S., Shewry, P. R., Tatham, A. S., Adams, G. G., Rowe, A. J.\& Harding, S. E. (2010). Structure and heterogeneity of gliadin: a hydrodynamic evaluation. European Biophysical Journal, 39, 255-261.

Anton, M., Martinet, V., Dalgalarrondo, M., Beaumal, V., David-Briand E.\& Rabesona, H. (2003). Structural and chemical characterisation of low-density lipoproteins purified from hen egg yolk. Food Chemistry, 83, 175-183. 
Audebrand, M., Ropers, M. H.\& Riaublanc, A. (2013). Disappearance of intermolecular beta-sheets upon adsorption of beta-lactoglobulin aggregates at the oil-water interfaces of emulsions. Food Hydrocolloids, 332, 178-185.

Belhomme, C., David-Briand, E., Ropers, M.-H., Guérin-Dubiard, C.\& Anton, M. (2007). Interfacial characteristics of spread films of hen egg yolk phosvitin at the air-water interface: Interrelation with its charge and aggregation state. Food Hydrocolloid, 21, 896-905.

Belhomme, C., David-Briand, E., Guérin-Dubiard, C., Vié, V.\& Anton, M. (2008). Phosvitin-calcium aggregation and organization at the air-water interface. Colloids and Surfaces B: Biointerfaces, 63, 1220.

Belton, P. S. (2005). New approaches to study the molecular basis of the mechanical properties of gluten. Journal of Cereal Science, 41, 203-211.

Ben Henda, Y.\& Bordenave-Juchereau, S. (2014). Using marine cryptides against metabolic syndrome. In: B. Hernandez-Ledesma\&Herrero, M. (eds) Bioactive compounds from marine food (pp 96-112). New Delhi: Wiley Blackwell.

Boire, A., Menut, P., Morel, M. H.\& Sanchez, C. (2013). Phase behaviour of a wheat protein isolate. Soft Matter, 9, 11414-11426.

Boire, A., Menut, P., Morel, M.-H.\& Sanchez, C. (2015). Osmotic compression of anisotropic proteins: Interaction properties and associated structures in wheat gliadin dispersions. Physical Chemistry $B$, $119,5412-5421$.

Boirie, Y., Dangin, M., Gachon, P., Vasson, M. P., Maubois, J. L.\& Beaufrere, B. (1997). Slow and fast dietary proteins differently modulate postprandial protein accretion. Proceedings of the National Academy of Sciences of the United States of America, 9426, 14930-14935.

Bos, C., Metges, C. C., Gaudichon, C., Petze, K. J., Pueyo, M. E., Morens, C., Everwand, J., Benamouzig, R.\& Tome, D. (2003). Postprandial kinetics of dietary amino acids are the main determinant of their metabolism after soy or milk protein ingestion in humans. Journal of Nutrition, 1335, 1308-1315.

Bouchoux, A., Gésan-Guiziou, G., Pérez, J.\& Cabane, B. (2010). How to squeeze a sponge: Casein micelles under osmotic stress, a SAXS study. Biophysical Journal, 99, 3754-3762.

Bouchoux, A., Qu, P., Bacchin, P.\& Gésan-Guiziou, G. (2014). A general approach for predicting the filtration of soft and permeable colloids: the milk example. Langmuir, 30, 22-34.

Bouchoux, A., Cayemitte, P. E., Jardin, J., Gésan-Guiziou, G.\& Cabane, B. (2009). Casein micelle dispersions under osmotic stress. Biophysical Journal, 96, 693-706.

Bouchoux, A., Debbou, B., Gésan-Guiziou, G., Famelart, M.-H., Doublier, J.-L.\& Cabane, B. (2009). Rheology and phase behavior of dense casein micelle dispersions. Journal of Chemical Physics, 131, 165106.

Carbonaro, M., Maselli, P.\& Nucara, A. (2012). Relationship between digestibility and secondary structure of raw and thermally treated legume proteins: a Fourier transform infrared FT-IR spectroscopic study. Amino Acids, 432, 911-921. 
Carbonaro, M., Cappelloni, M., Nicoli, S., Lucarini, M.\& Carnovale, E. (1997). Solubility-digestibility relationship of legume proteins. Journal of Agricultural and Food Chemistry, 459, 3387-3394.

Cardinaux, F., Gibaud, T., Stradner, A.\& Schurtenberger, P. (2007). Interplay between spinodal decomposition and glass formation in proteins exhibiting short-range attractions. Physical Review Letters, 99, 118301.

Daamen, W. F., Veerkamp, J. H., van Hest, J. C. M.\& van Kuppevelt, T. H. (2007). Elastin as a biomaterial for tissue engineering. Biomaterials, 28, 4378-4398.

Dahesh, M., Banc, A., Duri, A., Morel MH\& L., R. (2014). Polymeric assembly of gluten proteins in an aqueous ethanol solvent. Journal of Physical Chemistry B, 118, 11065-11076.

Dahesh, M., Banc, A., Duri, A., Morel MH\& L., R. (2016). Spontaneous gelation of wheat gluten proteins in a food grade solvent. Food Hydrocolloids, 52, 1-10.

Dangin, M., Guillet, C., Garcia-Rodenas, C., Gachon, P., Bouteloup-Demange, C., Reiffers-Magnani, K., Fauquant, J., Ballevre, O.\& Beaufrere, B. (2003). The rate of protein digestion affects protein gain differently during aging in humans. Journal of Physiology, 5492, 635-644.

Dauphas, S., Beaumal, V., Riaublanc, A.\& Anton, M. (2006). Hen egg yolk low-density lipoproteins film spreading at the air-water and oil-water interfaces. Journal of Agricultural and Food Chemistry, 54, 3733-3737.

Dauphas, S., Beaumal, V., Gunning, P., Mackie, A., Wilde, P., Vie, V., Riaublanc, A.\& Anton, M. (2007a). Structures and rheological properties of hen egg yolk low density lipoprotein layers spread at the air-water interface at pH 3 and 7. Colloids and Surfaces B-Biointerfaces, 57, 124-133.

Dauphas, S., Beaumal, V., Gunning, P., Mackie, A., Wilde, P., Vie, V., Riaublanc, A.\& Anton, M. (2007b). Structure modification in hen egg yolk low density lipoproteins layers between 30 and 45 $\mathrm{mn} / \mathrm{m}$ observed by AFM. Colloids and Surfaces B: Biointerfaces, 54, 241-248.

Descamps, E., Perrot, N., Trelea, L. C., Gaucel, S., Riaublanc, A., Mackie, A.\& Lutton, E. (2014). Coupling deterministic and random sequential approaches for structure and texture prediction of a dairy oil-in-water emulsion. Innovative Food Science \& Emerging Technologies, 25, 28-39.

Desfougères, Y., Lechevalier, V., Pezennec, S., Artzner, F.\& Nau, F. (2008). Dry-heating makes hen egg white lysozyme an efficient foaming agent and enables its bulk aggregation. Journal of Agricultural \& Food Chemistry, 56, 5120-5128.

Desfougères, Y., Croguennec, T., Lechevalier, V., Bouhallab, S.\& Nau, F. (2010). Charge and size drive spontaneous self-assembly of oppositely charged globular proteins into microspheres. Journal of Physical Chemistry B, 114, 4138-4144.

Desfougères, Y., Jardin, J., Lechevalier, V., Pezennec, S.\& Nau, F. (2011). Succinimidyl residue formation in hen egg-white lysozyme favors the formation of intermolecular covalent bonds without affecting its tertiary structure. Biomacromolecules, 12, 156-166. 
Desfougères, Y., Saint-Jalmes, A., Salonen, A., Vié, V., Beaufils, S., Pezennec, S., Desbat, B., Lechevalier, V.\& Nau, F. (2011). Strong improvement of interfacial properties can result from slight structural modifications of proteins: the case of native and dry-heated lysozyme. Langmuir, 27, 14947-14957.

Ferraro, V., Anton, M.\& Santé-Lhoutellier, V. (2016). The "sisters" ?-helices of collagen, elastin and keratin recovered from animal by-products: functionality, bioactivity and trends of applications. Trends in Food Science \& Technology, 51, 65-75.

Filipello Marchisio, V. (2000). Keratinophilic fungi: their role in nature and degradation of keratinic substances. Revista Iberoamericana de Micologia

Fleming, A. (1922). On a remarkable bacteriolytic element found in tissues and secretions. Proceedings of the Royal Society of London B, 93, 306-317.

Fouillet, H., Mariotti, F., Gaudichon, C., Bos, C.\& Tome, D. (2002). Peripheral and splanchnic metabolism of dietary nitrogen are differently affected by the protein source in humans as assessed by compartmental modeling. Journal of Nutrition, 1321, 125-133.

Gibaud, T., Cardinaux, F., Bergenholtz, J., Stradner, A.\& Schurtenberger, P. (2011). Phase separation and dynamical arrest for particles interacting with mixed potentials-the case of globular proteins revisited. Soft Matter, 7, 857-860. 10.1039/COSM01175D

Giménez, M. A., Drago, S. R., Bassett, M. N., Lobo, M. O.\& Sammán, N. C. (2016). Nutritional improvement of corn pasta-like product with broad bean (Vicia faba) and quinoa (Chenopodium quinoa). Food Chemistry, 199, 150-156. http://dx.doi.org/10.1016/j.foodchem.2015.11.065

Greffeuille, V., Marsset-Baglieri, A., Molinari, N., Cassan, D., Sutra, T., Avignon, A.\& Micard, V. (2015). Enrichment of pasta with faba bean does not impact glycemic or insulin response but can enhance satiety feeling and digestive comfort when dried at very high temperature. Food \& Function, 69, 2996-3005.

Hamer, R. J., van Vliet, T.\& Lefebvre, J. (2005). Letter to editor. Journal of Cereal Science, 42, 344345.

Hara, H., Nishikawa, H.\& Kiriyama, S. (1992). Different effects of casein and soybean protein on gastric-emptying of protein and small intestinal transit after spontaneous feeding of diets in rats. British Journal of Nutrition, 681, 59-66.

Holt, C., Carver, J. A., Ecroyd, H.\& Thorn, D. C. (2013). Invited review: Caseins and the casein micelle: Their biological functions, structures, and behavior in foods. Journal of Dairy Science, 96, 6127-6146.

Horne, D. S. (2006). Casein micelle structure: Models and muddles. Current Opinions in Colloid Interface Science, 11, 148-153.

Kastorini, C. M., Milionis, H. J., Goudevenos, J. A.\& Panagiotakos, D. B. (2010). Mediterranean diet and coronary heart disease: Is obesity a link? - A systematic review. Nutrition Metabolism and Cardiovascular Diseases, 207, 536-551. 
Laleg, K., Cassan, D., Abecassis, J.\& Micard, V. (2016) Procede de fabrication de pate destinee a I'alimentation humaine et/ou animale comprenant au moins 35\% de legumineuse. In: INRA-SupAgro (ed). WO2016097328 A1. 23 juin 2016, Google Patents., France

Laleg, K., Barron, C., Sante-Lhoutellier, V., Walrand, S.\& Micard, V. (2016). Protein enriched pasta: structure and digestibility of its protein network. Food \& Function, 72, 1196-1207.

Laleg, K., Barron, C., Cordelle, S., Schlich, P., Walrand, S.\& Micard, V. (2016). How the structure, nutritional and sensory attributes of pasta made from legume flour is affected by the proportion of legume protein. Submitted to LWT

Laleg, K., Cassan, D., Barron, C., Prabhasankar, P., \& Micard, V. (2016). Structural, Culinary, Nutritional and Anti-Nutritional Properties of High Protein, Gluten Free, 100\% Legume Pasta. PLoS ONE, 119

Le Floch-Fouéré, C., Pezennec, S., Pézolet, M., Rioux-Dubé, J.-F., Renault, A.\& Beaufils, S. (2011). Unexpected differences in the behavior of ovotransferrin at the air-water interface at pH 6.5 and 8.0. Journal of Colloid Interface Science, 356, 614-623.

Le Floch-Fouéré, C., Pezennec, S., Pasco, M., Paboeuf, G., Renault, A.\& Beaufils, S. (2015). Moderate conformational impact of citrate on ovotransferrin considerably increases its capacity to selfassemble at the interface. Journal of Colloid Interface Science, 437, 219-226.

Le Floch-Fouéré, C., Pezennec, S., Lechevalier, V., Beaufils, S., Desbat, B., Pézolet, M.\& Renault, A. (2009). Synergy between ovalbumin and lysozyme leads to non-additive interfacial and foaming properties of mixtures. Food Hydrocolloids, 23, 352-365.

Le Floch-Fouéré, C., Beaufils, S., Lechevalier, V., Nau, F., Pézolet, M., Renault, A.\& Pezennec, S. (2010). Sequential adsorption of egg-white proteins at the air-water interface suggests a stratified organization of the interfacial film. Food Hydrocolloids, 24, 275-284.

Lechevalier, V., Croguennec, T., Pezennec, S., Guérin-Dubiard, C., Pasco, M.\& Nau, F. (2003). Ovalbumin, ovotransferrin, lysozyme: three model proteins for structural modifications at the air?water interface. Journal of Agricultural \& Food Chemistry, 51, 6354-6361.

LeNeveu, D. M., Rand, R. P.\& Parsegian, V. A. (1976). Measurement of forces between lecithin layers. Nature, 259, 601-603.

Liu, D., Nikoo, M., Boran, G., Zhou, P.\& Regenstein, J. M. (2015). Collagen and Gelatin. Annual Reviews of Food Science and Technology, 6, 527-557.

Loiseleux, T., Garnier C., Beaumal V., Croguennec T., Guilois S., Jonchère C., Roland-Sabaté A., Anton M.\& Riaublanc, A. (2017). Mechanisms of flocculation in low fat dairy emulsion containing whey proteins aggregates. Food Hydrocolloids, in press

MacRitchie, F. (2007). Letter to editor. Journal of Cereal Science, 46, 96-97.

Mahmoudi, N., Axelos, M. A. V.\& Riaublanc, A. (2011). Interfacial properties of fractal and spherical whey protein aggregates. Soft Matter, 717, 7643-7654. 
Mahmoudi, N., Gaillard, C., Boue, F., Axelos, M. A. V.\& Riaublanc, A. (2010). Self-similar assemblies of globular whey proteins at the air-water interface: Effect of the structure. Journal of Colloid and Interface Science, 3451, 54-63.

Mahmoudi, N., Gaillard, C., Riaublanc, A., Boue, F.\& Axelos, M. A. V. (2014). Transition from Fractal to Spherical Aggregates of Globular Proteins: Brownian-Like Activation and/or Hydrodynamic Stress? Current Topics in Medicinal Chemistry, 145, 630-639.

Martinet, V., Beaumal, V., Dalgalarrondo, M.\& Anton, M. (2002). Emulsifying properties and adsorption behavior of egg yolk lipoproteins LDL and HDL in o/w emulsions. Recent Research Developments in Agricultural and Food Chemistry, 37, 103-116.

Martinet, V., Saulnier, P., Beaumal, V., Couthaudon, J.-L.\& Anton, M. (2003). Surface properties of hen egg yolk low-density lipoproteins spread at the air-water interface. Colloids and Surfaces $B$ : Biointerfaces, 31, 185-194.

Nicorescu, I., Loisel, C., Riaublanc, A., Vial, C., Djelveh, G., Cuvelier, G.\& Legrand, J. (2009). Effect of dynamic heat treatment on the physical properties of whey protein foams. Food Hydrocolloids, 23, 1209-1219 DOI: 10.1016/j.foodhyd.2008.09.005

Nigen, M., Croguennec, T.\& Bouhallab, S. (2009). Formation and stability of ?-lactalbumin-lysozyme spherical particles: Involvement of electrostatic forces. Food Hydrocolloids, 23, 510-518.

Nigen, M., Croguennec, T., Renard, D.\& Bouhallab, S. (2007). Temperature affects the supramolecular structures resulting from ?-lactalbumin?lysozyme interaction. Biochemistry, 46, 1248-1255.

Nigen, M., Le Tilly, V., Croguennec, T., Drouin-Kucma, D.\& Bouhallab, S. (2009). Molecular interaction between apo or holo $\alpha$-lactalbumin and lysozyme: Formation of heterodimers as assessed by fluorescence measurements. Biochimica et Biophysica Acta - Proteins and Proteomics, 1794, 709715.

Nigen, M., Le Tilly, V., Croguennec, T., Drouin-Kucma, D.\& Bouhallab, S. (2010). Dynamic and supramolecular organisation of a-lactalbumin/lysozyme microspheres: A microscopic study. Biophysical Chemistry, 146, 30-35.

Parsegian, V., Rand, R., Fuller, N.\& Rau, D. (1986). Osmotic stress for the direct measurement of intermolecular forces. Methods in enzymology, 127, 400-416.

Pasquier, C., Beaufils, S., Bouchoux, A., Rigault, S., Cabane, B., Lund, M., Lechevalier, V., Le FlochFouere, C., Pasco, M., Paboeuf, G., Perez, J.\& Pezennec, S. (2016). Osmotic pressures of lysozyme solutions from gas-like to crystal states. Physical Chemistry Chemical Physics, 18, 28458-28465.

Peixoto, P. D. S., Tavares, G. M., Croguennec, T., Nicolas, A., Hamon, P., Roiland, C.\& Bouhallab, S. (2016). Structure and dynamics of heteroprotein coacervates. Langmuir, 32, 7821-7828.

Petitot, M., Barron, C., Morel, M.-H.\& Micard, V. (2010). Impact of Legume Flour Addition on Pasta Structure: Consequences on Its In Vitro Starch Digestibility. Food Biophysics, 54, $284-299$.

Petitot, M., Boyer, L., Minier, C.\& Micard, V. (2010). Fortification of pasta with split pea and faba bean flours: Pasta processing and quality evaluation. Food Research International, 432, 634-641. 
Pezennec, S., Gauthier, F., Alonso, C., Graner, F., Croguennec, T., Brulé, G.\& Renault, A. (2000). The protein net electric charge determines the surface rheological properties of ovalbumin adsorbed at the air-water interface. Food Hydrocolloids, 14, 463-472.

Qi, P. X. (2007). Studies of casein micelle structure: the past and the present. Lait, 87, 363-383.

Rajiv, J., Milind, Suresh, D.S., , Aashitosh, A. I.\& Venkateswara Rao, G. (2014). Effect of green gram semolina Phaseolus aureus on the rheology, nutrition, microstructure and quality characteristics of high-protein pasta. Journal of Food Processing and Preservation, 384, 1965-1972.

Renault, A., Pezennec, S., Gauthier, F., Vié, V.\& Desbat, B. (2002). Surface rheological properties of native and s-ovalbumin are correlated with the development of an intermolecular ?-sheet network at the air?water interface. Langmuir, 18, 6887-6895.

Rosa-Sibakov, N., Heinio, R.-L., Cassan, D., Holopainen-Mantila, U., Micard, V., Lantto, R.\& Sozer, N. (2016). Effect of bioprocessing and fractionation on the structural, textural and sensory properties of gluten-free faba bean pasta. LWT - Food Science and Technology, 67, 27-36.

Salvatore, D., Croguennec, T., Bouhallab, S., Forge, V.\& Nicolai, T. (2011). Kinetics and structure during self-assembly of oppositely charged proteins in aqueous solution. Biomacromolecules, 12, 1920-1926.

Salvatore, D. B., Duraffourg, N., Favier, A., Persson, B. A., Lund, M., Delage, M.-M., Silvers, R., Schwalbe, H., Croguennec, T., Bouhallab, S.\& Forge, V. (2011). Investigation at residue level of the early steps during the assembly of two proteins into supramolecular objects. Biomacromolecules, 12, $2200-2210$.

Schwartz, J.-M., Solé, V., Guéguen, J., Ropers, M.-H., Riaublanc, A.\& Anton, M. (2015). Partial replacement of ?-casein by napin, a rapeseed protein, as ingredient for processed foods: Thermoreversible aggregation. LWT - Food Science \& Technology, 63, 562-568.

Shoulders, M. D.\& Raines, R. T. (2009). Collagen structure and stability. Annual Review of Biochemistry, 78, 929-958.

Sozer, A. N., Rosa-Sibakov, N.\& Sibakov, J. (2015) Gluten-free pasta and method for the manufacture of gluten-free pasta. In: Oy, T. T. V. (ed). WO2015158960 A1. 22 oct. 2015, Google Patents, Finlande

Surel, C., Foucquier, J., Perrot, N., Mackie, A., Garnier, C., Riaublanc, A.\& Anton, M. (2014). Composition and structure of interface impacts texture of $\mathrm{O} / \mathrm{W}$ emulsions. Food Hydrocolloids, 34, 39.

Tavares, G. M., Croguennec, T., Carvalho, A. F.\& Bouhallab, S. (2014). Milk proteins as encapsulation devices and delivery vehicles: Applications and trends. Trends Food Science \& Technology, 37, 5-20.

Tavares, G. M., Croguennec, T., Hamon, P., Carvalho, A. F.\& Bouhallab, S. (2015). Selective coacervation between lactoferrin and the two isoforms of $\beta$-lactoglobulin. Food Hydrocolloids, 48, 238-247. 
Thomson, N. H., Miles, M. J., Popineau, Y., Harries, J., Shewry, P.\& Tatham, A. S. (1999). Small angle $X$-ray scattering of wheat seed-storage proteins: $\alpha-, \gamma$ - and $\omega$-gliadins and the high molecular weight (HMW) subunits of glutenin. Biochimica et Biophysica Acta - Protein Structure and Molecular Enzymology, 1430, 359-366.

Torres, A., Frias, J., Granito, M., Guerra, M.\& Vidal-Valverde, C. (2007). Chemical, biological and sensory evaluation of pasta products supplemented with alpha-galactoside-free lupin flours. Journal of the Science of Food and Agriculture, 871, 74-81.

Vasconcelos, A.\& Cavaco-Paulo, A. (2013). The use of keratin in biomedical applications. Current Drug Targets, 14, 612-613.

Wood, J. A. (2009). Texture, processing and organoleptic properties of chickpea-fortified spaghetti with insights to the underlying mechanisms of traditional durum pasta quality. Journal of Cereal Science, 491, 128-133. 
Highlights - Proteins for the future: a soft matter approach to link basic knowledge and innovative applications

- Protein interactions play a key role in determining the final structure and properties of products

- Interfacial protein crowding generates intermolecular interactions that impacts surface properties

- Protein-protein interactions can be quantified by measuring the osmotic pressure in solution

- Fundamental and applied aspects of complex coacervation in heteroprotein systems are detailed

- Applications in animal bioproducts, pasta products and nutriment encapsulation are highlighted 